\title{
ANALISIS KOLOM BETON BERTULANG PADA PENAMPANG PERSEGI BERLUBANG
}

\author{
Amrun Nasution ${ }^{1)}$, Mukhlis Islam ${ }^{2)}$ \\ ${ }^{1), 2)}$ Program Studi Teknik Sipil, Fakultas Teknik, Universitas Bengkulu \\ Corresponding Author: amrunnasution@gmail.com
}

\begin{abstract}
Abstrak
Pemasangan pipa didalam kolom (konduit) seperti instalasi pipa listrik dan sanitasi pada struktur kolom beton bertulang menyebabkan kolom itu menjadi berlubang. Berkurangnya luas penampang pada kolom dapat mengakibatkan berkurangnya kekuatan suatu kolom. Tujuan penelitian ini adalah untuk mengetahui perbedaan kekuatan kolom beton berlubang dengan kolom beton tidak berlubang dan menghasilkan suatu analisis berupa grafik-grafik interaksi gaya aksial $\left(\mathrm{P}_{n}\right)$ dan momen nominal $\left(\mathrm{M}_{\mathrm{n}}\right)$. Metode analisis kolom persegi dikembangkan dengan menggunakan aplikasi spread sheet dan menggunakan hubungan tegangan-regangan Hognestad. Analisis kolom persegi berlubang pada penelitian ini sebanyak 720 sampel. Penelitian ini menggunakan dimensi 300x300-600x600 mm dengan kenaikan 100 $\mathrm{mm}$. Mutu beton $\left(\mathrm{f}^{\prime} \mathrm{c}\right)$ yang digunakan yaitu 25-30 MPa dengan kenaikan 2,5 MPa. Mutu tulangan ( $\left.\mathrm{f}_{\mathrm{y}}\right)$ yang digunakan yaitu $400 \mathrm{MPa}$ dan rasio luas tulangan diambil dari 1\%-8\% dengan kenaikan 2\% dari luas penampang kolom, dengan jumlah tulangan sebanyak 12-20 buah tulangan dengan kenaikan 4 buah. Luas lubang yang digunakan yaitu 3\%-7\% dengan kenaikan $1 \%$. Hasil analisis menunjukkan terjadi penurunan $\mathrm{P}_{\mathrm{n}}-\mathrm{M}_{\mathrm{n}}$ kolom berlubang terhadap kolom tidak berlubang. Penurunan $\mathrm{P}_{\mathrm{n}}$ maksimal sebesar 7,20\% pada luasan lubang $7 \%$ dengan eksentrisitass terhadap d sebesar 8,01\% dan penurunan $\mathrm{M}_{\mathrm{n}}$ maksimal sebesar $10,91 \%$ pada luasan lubang $7 \%$ dengan eksentrisitas terhadap d sebesar $20,51 \%$.
\end{abstract}

Kata kunci: kolom beton bertulang, kolom berlubang, kolom beton tidak berlubang, teganganregangan Hognestad, kekuatan kolom

\begin{abstract}
Installation of the pipe in the column (conduit) such as electrical and sanitary plumbing installations are found in the structure of reinforced concrete columns. This causes it to be a hollow column. The existence of holes cause a reduction in cross sectional area of the column and can result in reduced strength of a column. The purpose of this study was to know the power difference hollow concrete columns with concrete columns are not hollow and produce an analysis of the interaction in the form graphics axial force $\left(P_{n}\right)$ and nominal torque $\left(M_{n}\right)$. The analytical method developed by using square column spread sheet applications and use the stress-strain relationship hognestad. Analysis of the hollow square column in this study as many as 720 samples. This study used 300x300-600x600 mm dimensions with an increase of 100 mm. Quality concrete $\left(f^{\prime} c\right)$ used was 25-30 MPa to 2,5 MPa rise. Quality reinforcement (fy) used was 400 MPa and the ratio of the reinforcement taken from 1\%-8\% with an increase of $2 \%$ of the cross sectional area of the column, with the amount of reinforcement as much as 12-20 pieces of reinforcement to rise 4 pieces. Widely used hole that is 3\% -7\%, with an increase of $1 \%$. The analysis showed a decrease in Pn-Mn hollow column to column was not perforated. The decrease Pn maximum of 7,20\% in the area of hole 7\% by eccentricity to d amounting to $8.01 \%$ and the maximum Mn decrease of $10.91 \%$ in the area of hole $7 \%$ by eccentricity to d amounting to $20,51 \%$.
\end{abstract}

Keywords: reinforced concrete columns, columns punched, punched no concrete columns, stress-strain Hognestad, column strength 


\section{PENDAHULUAN}

Kolom adalah komponen struktur bangunan yang tugas utamanya menyangga beban aksial tekan vertikal, dengan bagian tinggi tidak ditopang paling tidak tiga kali dimensi lateral terkecil. Kolom berfungsi sebagai penerus beban seluruh bangunan ke pondasi (SNI 2847-2013).

Kekuatan kolom dalam memikul beban didasarkan pada kemampuannya memikul kombinasi beban aksial $\left(\mathrm{P}_{\mathrm{u}}\right)$ dan momen $\left(\mathrm{M}_{\mathrm{u}}\right)$ secara bersamaan. Perencanaan kolom suatu struktur bangunan didasarkan pada kekuatan dan kekakuan penampang lintangnya terhadap aksi beban aksial dan momen lentur. Diagram interaksi digunakan untuk mengetahui kekuatan penampang kolom, yaitu suatu grafik daerah batas yang menunjukkan kombinasi beban aksial dan momen yang dapat ditahan oleh kolom secara aman (Wahyudi, 1997).

Pemasangan pipa pada kolom bangunan (conduit) banyak ditemukan dalam struktur beton bertulang. Pemasangan pipa ini dianggap menguntungkan karena pipa didalam kolom dapat dimanfaatkan sebagai saluran listrik, air hujan, air kotor, dan sebagainya. Pemasangan pipa pada kolom menyebabkan kolom itu menjadi berlubang. Keberadaan lubang menyebabkan berkurangnya luas penampang pada kolom dan dapat mengakibatkan berkurangnya kekuatan suatu kolom. Kegagalan suatu kolom biasanya terjadi akibat dari terlalu besarnya lubang pada kolom ataupun tidak sentrisnya pemasangan pipa pada kolom tersebut (Renaningsih, 2006).

SNI 2847-2013 pasal 6.3. menyebutkan, pipa bersama kaitnya yang ditanam pada kolom tidak boleh menempati lebih dari 4 persen luas penampang yang diperlukan untuk kekuatan atau untuk perlindungan terhadap kebakaran. Pemasangan pipa pada kolom sering dilakukan tanpa memperhitungkan perbedaan kekuatan antara kolom berlubang dan kolom tidak berlubang. Tujuan penelitian ini untuk mengetahui perbedaan dan seberapa besar pengaruh lubang terhadap pengurangan kekuatan kolom berlubang dan kolom tidak berlubang peneliti mencoba meniliti dengan judul "analisis kolom beton bertulang pada penampang persegi berlubang (studi kasus tulangan longitudinal empat muka)".

\section{Kolom}

Kolom adalah komponen struktur bangunan yang tugas utamanya menyangga beban aksial desak vertikal dengan bagian tinggi yang tidak ditopang paling tidak tiga kali dimensi lateral terkecil. Kolom berfungsi sebagai pendukung beban-beban dari balok dan pelat, untuk diteruskan ke tanah melalui dasar pondasi pada suatu konstruksi bangunan gedung. Beban dari balok dan pelat ini berupa beban aksial tekan serta momen lentur ( (SNI 2847-2013).

Menurut jenisnya, kolom dapat dibedakan atas beberapa bentuk dan susunan tulangan, serta posisi beban aksial pada penampang kolom. Kolom juga dapat dibedakan menurut ukuran panjang-pendeknya kolomdalam hubungannya dengan dimensi lateral (Asroni, 2010).

\section{Jenis kolom berdasarkan letak dan posisi beban aksial}

Berdasarkan letak beban aksial (P) yang berkerja pada penampang kolom, kolom dibedakan menjadi dua macam, yaitu kolom dengan posisi beban sentris dan kolom dengan posisi beban eksentris. Kolom dengan posisi beban sentris bisa disebut dengan kolom uniaksial dan kolom 
dengan posisi beban eksentris kolom biaksial.

Kolom dengan posisi beban sentris yaitu beban aksial yang bekerja di sumbu kolom dan kolom dengan posisi beban eksentris yaitu beban aksial yang berkerja di luar sumbu kolom dengan eksentrisitas sebesar e. Beban aksial dan eksentrisitas ini akan menimbulkan momen sebesar P dikali e (Asroni, 2010).

\section{Tegangan-Regangan ( $\sigma-\varepsilon)$ Hognestad}

Tegangan maksimum yang diperoleh melalui pengujian mesin akan memberikan kekuatan tarik pada beton. Proses ini menimbulkan batas regangan maka didapat kurva tegangan-regangan beton. Dari hasil pengujian kurva dapat ditetapkan model Hognestad untuk menentukan distribusi tegangan yang bersifat non-linier atau bagian parabola (Riadi, 2012). Diagram teganganregangan $(\sigma-\varepsilon)$ beton normal menurut hognestad seperti pada Gambar 1.

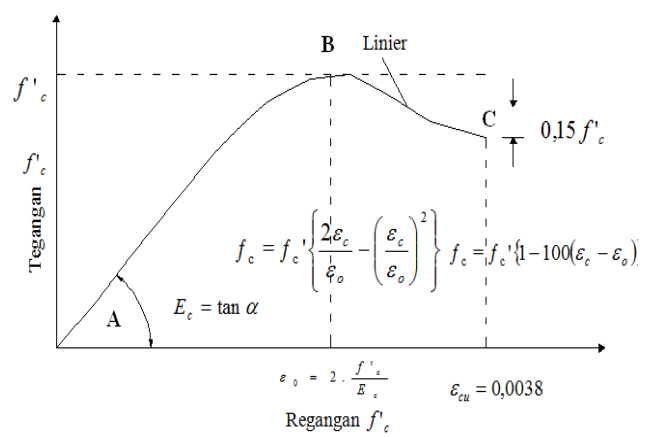

Gambar 1. Kurva $(\sigma-\varepsilon)$ Beton Normal Menurut Hognestad

\section{Metode-metode desain kolom}

Menurut asroni (2010), metode perencanaan kolom pada dasarnya dapat dilaksanakan dengan dua cara, yaitu perencanaan dengan menggunakan diagram dan perencanaan dengan analisis.

\section{Perencanaan menggunakan diagram}

Beban yang bekerja pada kolom, biasanya berupa beban aksial dan momen lentur. Besar beban aksial dan momen lentur yang mampu ditahan kolom tergantung pada ukuran/dimensi kolom dan jumlah serta letak baja tulangan yang ada/terpasang pada kolom tersebut. Hubungan antara beban aksial dan momen lentur digambarkan dalam suatu diagram yang disebut diagram interaksi kolom $\mathrm{P}_{\mathrm{n}}-\mathrm{M}_{\mathrm{n}}$, yaitu dapat memberikan gambaran tentang kekutan dari kolom tersebut.

Perencanaan tulangan dengan bantuan diagram merupakan cara praktis yang mudah untuk dilaksanakan. Diagram ini mempunyai dua sumbu utama, yaitu sumbu vertikal dan sumbu horizontal. Kedua sumbu tersebut dapat digunakan untuk mendesain berbagai macam ukuran penampang kolom.

Meskipun cara ini mudah dan praktis untuk dilaksanakan, tetapi punya kelemahan terutama pada mutu beton, lebar penampang, lebar lubang ataupun baja tulangan tidak sesuai dengan yang tercantum pada diagram, maka perencanaan tulangan kolom akan terhambat atau tidak dapat terlaksana (Asroni, 2010).

\section{Perencanaan dengan analisis}

Perencanaan dengan cara analisis mempunyai kelebihan bila dibandingkan dengan cara perencanaan kolom dengan diagram, terutama dalam hal berikut:

a. Dapat dipakai pada sembarang mutu beton dan mutu baja tulangan.

b. Hasil hitungan lebih akurat, karena dihitung berdasarkan rumus•rumus yang telah dijabarkan/dianalisis secara lebih rinci (Asroni, 2010).

\section{Ketentuan perencanaan}

Beberapa ketentuan penting untuk diperhatikan dalam perencanaan kolom 
meliputi hal-hal berikut :

1. Luas tulangan total ( $\mathrm{A}_{\text {st }}$ )

Pasal 10.9.1 SNI 2847-2013, luas total tulangan longitudinal (tulangan memanjang) kolom harus memenuhi syarat sebagai berikut :

$$
0,01 \mathrm{~A}_{\mathrm{g}} \leq \mathrm{A}_{\mathrm{st}} \leq 0,08 \mathrm{~A}_{\mathrm{g}}
$$

2. Diameter tulangan geser (begel)

Diameter tulangan geser disyaratkan

$$
10 \mathrm{~mm} \leq \text { Øbegel } \leq 16 \mathrm{~mm}
$$

3. Gaya tarik dan tekan pada penampang kolom

Kolom yang sering dijumpai/ digunakan pada bangunan gedung, yaitu kolom dengan penampang segi empat. Jika kolom menahan beban eksentris $\mathrm{P}_{\mathrm{n}}$, maka pada penampang kolom sebelah kiri menahan beban tarik yang ditahan oleh baja tulangan, sedangkan sebelah kanan menahan beban tekan yang akan ditahan oleh beton dan baja tulangan.
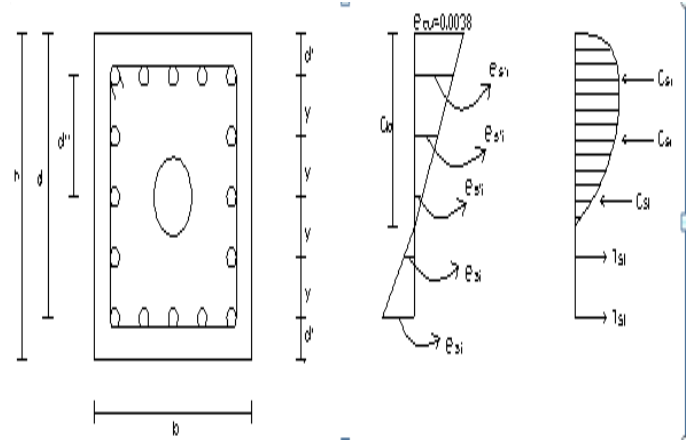

Gambar 2. Tegangan-Regangan Penampang Kolom

Gaya tarik bagian kiri ditahan oleh tulangan, sebesar:

$$
\mathrm{T}_{\mathrm{S}}=\mathrm{A}_{\mathrm{S}} \cdot \mathrm{F}_{\mathrm{S}}
$$

Sedangkan gaya tekan yang ditahan oleh tulangan kanan $\left(\mathrm{C}_{\mathrm{S}}\right)$, yaitu :

a. Jika luas beton diperhitungkan, maka

$$
\mathrm{C}_{\mathrm{S}}=\mathrm{A}_{\mathrm{s}}{ }^{\prime} \cdot\left(\mathrm{f}_{\mathrm{s}}{ }^{\prime}-0,85 \mathrm{f}^{\prime} \mathrm{c}\right)
$$

b. Jika luas beton tekan diabaikan, maka

$$
\mathrm{C}_{\mathrm{S}}=\mathrm{A}_{\mathrm{S}} \cdot \mathrm{f}_{\mathrm{S}}
$$

Selanjutnya dengan memperhatikan keseimbangan gaya vertikal, diperoleh gaya aksial

$$
\begin{aligned}
& P_{n}=C_{\mathrm{c}}+C_{\mathrm{S}}-\mathrm{T}_{\mathrm{S}} \\
& M_{n}=\sum C_{c i} \cdot\left(d-d^{\prime \prime}-((i-1) x+x / 2)+C_{S} \cdot\left(d-d^{\prime \prime}-d^{\prime \prime}\right)+T_{S} \cdot\left(d^{\prime \prime}\right)\right.
\end{aligned}
$$

\section{METODE PENELITIAN}

Penelitian ini dilakukan menggunakan jenis penelitian terapan. Penelitian terapan adalah salah satu jenis penelitian untuk memberikan solusi atas permasalahan tertentu secara praktis (Wikipedia, 2010). Dalam hal ini, peneliti akan mencoba meneliti mengenai grafik interaksi antara $\mathrm{P}_{\mathrm{n}}-\mathrm{M}_{\mathrm{n}}$ kolom persegi berlubang tulangan longitudinal empat muka. Inti dari penelitian adalah menganalisis pengaruh lubang terhadap kekuatan kolom persegi. Metode analisis kolom persegi dikembangkan dengan menuggunakan aplikasi spread sheet dan menggunakan hubungan tegangan regangan Hognestad.

\section{Metode Analisis}

Analisis kolom persegi berlubang ini dikembangkan dengan menggunakan aplikasi spread sheet. Adapun penjelasan tahap-tahap analisis dalam penelitian kolom persegi berlubang mengunakan hubungan tegangan- regangan $(\sigma-\varepsilon)$ Hognestad adalah sebagai berikut:

1. Asumsi-asumsi

Pada langkah awal penelitian, peneliti melakukan asumsi-asumsi terhadap beberapa hal yang diketahui, antara lain :

a. Kolom beton bertulang berpenampang persegi dengan tulangan longitudinal empat muka.

b. Elemen struktur beton bertulang yang hanya mengalami kombinasi momen lentur uniaksial. 
c. Menggunakan aplikasi spread sheet yang dapat mengolah data dengan cepat, sistematis dan akurat.

d. Mutu beton (f'c) yang diambil merupakan mutu beton normal mulai dari 25-30 MPa dengan kenaikan 2,5 MPa.

e. Mutu tulangan baja (fy) sebesar 400 $\mathrm{MPa}$.

f. Jumlah tulangan longitudinal (12-20) buah dengan kenaikan 4 buah.

g. Tulangan dari 1\% $1 \%$ dengan kenaikan sebesar 2\% (SNI-2847-2013).

h. Dimensi kolom persegi (30-60) cm dengan kenaikan $10 \mathrm{~cm}$.

i. Luas lubang (3-7) \% dengan kenaikan $1 \%$ (berdasarkan SNI-2847-2013 luas lubang maksimum 4\%).

j. Teori regangan beton yang dipakai yaitu teori tegangan- regangan hognestad dengan nilai $\varepsilon c u=0,0038 \mathrm{~mm}$.

k. Modulus elastisitas baja (Es) sebesar $200000 \mathrm{MPa}$

1. Rencana pias teganganregangan hognestad penampang kolom persegi empat muka (Gambar 3)

m. Grafik interaksi Pn-Mn dan teganganregangan beton metode hognestasd seperti Gambar 4.

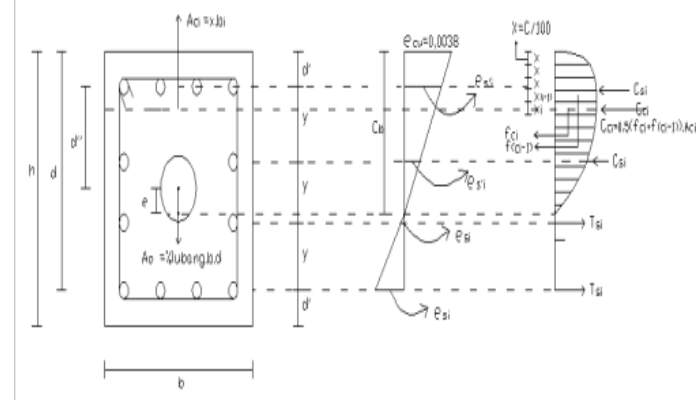

Gambar 3. Rencana Tegangan-Regangan Hognestad

\section{HASIL DAN PEMBAHASAN}

Analisis Kolom Persegi Berlubang Analisis kolom persegi berlubang pada penelitian ini, penulis menggunakan asumsi-asumsi dasar yang biasa digunakan dalam perhitungan struktur kolom. Untuk satu nilai jarak tertentu (C) dibagi menjadi 100 bagian. Pada satu jarak nilai $\mathrm{C}$ juga dihasilkan satu gaya aksial nominal $\left(\mathrm{P}_{\mathrm{n}}\right)$ dan momen nominal $\left(\mathrm{M}_{\mathrm{n}}\right)$. Titik-titik dari masing- masing nilai $\mathrm{P}_{\mathrm{n}}$ dan $\mathrm{M}_{\mathrm{n}}$ untuk tiap nilai $\mathrm{C}$ tersebut digabungkan sehingga menjadi grafik interaksi $P_{n}$ dan $M_{n}$. Penelitian ini menggunakan analisis berulang untuk tiap dimensi, mutu beton, jumlah tulangan, luas lubang dan luas tulangan yang berbeda-beda. Adapun hasil akhir analisis ini akan didapatkan suatu grafik interaksi $P_{n}$ dan $M_{n}$. Nilai $P_{n}$ dan $M_{n}$ antara kolom berlubang dan kolom tidak berlubang berbeda. Perbedaan nilai $\mathrm{P}_{\mathrm{n}}$ dan $\mathrm{M}_{\mathrm{n}}$ antara kolom belubang dan kolom tidak berlubang yaitu terjadi penurunan nilai $P_{n}$ dan $M_{n}$. Penurunan nilai $P_{n}$ dan $M_{n}$ terjadi karena luas penampang kolom berkurang akibat lubang. $P_{n}$ dan $M_{n}$ pada kondisi tarik pada kolom tidak berlubang dan kolom berlubang menghasilkan selisih nilai $\mathrm{P}_{\mathrm{n}}$ dan $\mathrm{M}_{\mathrm{n}}$ sedikit. Selisih tersebut terlihat ketika grafik memasuki kondisi balance (kondisi seimbang). Selisih gaya aksial dan momen nominal terlihat jelas pada kondisi tekan. Perbedaan antara kolom berlubang dengan kolom tidak berlubang dapat dilihat pada Gambar 5.

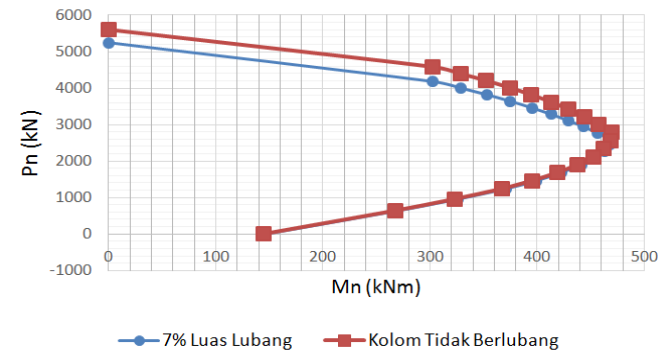

Gambar 4. Grafik Interaksi $P_{n}$ dan $M_{n}$ Kolom 


\section{Persentase Selisih $P_{n}$ Kolom Persegi Berlubang Terhadap Kolom Tidak Berlubang}

Grafik persentase selisih $\mathrm{P}_{\mathrm{n}}$ terhadap besaran eksentrisitas memperlihatkan penurunan selisih $\mathrm{P}_{\mathrm{n}}$ untuk masing- masing lubang. Dari grafik dapat dilihat bahwa nilai $P_{n}$ pada kondisi tekan mengalami kenaikan (tiitk A) dan pada tititk tertentu pada kondisi tekan terdapat titik puncak (titik B) serta grafik akan akan mengalami penurunan pada kondisi tarik (titik C) seperti pada Gambar 5. Hal ini disebabkan karena posisi penurunan, gaya aksial bersentuhan langsung dengan lubang.

Persentase selisih $P_{n}$ terhadap besaran eksentrisitas dipengaruhi oleh beberapa faktor, yaitu: luas tulangan, jumlah tulangan, mutu beton, dimensi kolom.

1. Luas Tulangan

Persentase selisih $P_{n}$ tetap ketika luas tulangan diperbesar, akan tetapi jarak eksentrisitas terhadap d semakin besar ketika luas tulangan diperbesar.

\section{Jumlah Tulangan}

Persentase selisih $\mathrm{P}_{\mathrm{n}}$ tetap ketika jumlah tulangan tulangan diperbanyak, akan tetapi jarak eksentrisitas terhadap d semakin kecil ketika jumlah tulangan diperbanyak.

\section{Mutu Beton}

Persentase selisih $\mathrm{P}_{\mathrm{n}}$ semakin besar ketika mutu beton semakin besar dan jarak eksentrisitas terhadap d semakin kecil ketika mutu beton diperbesar.

\section{Dimensi Kolom}

Persentase selisih $\mathrm{P}$ semakin besar apabila dimensi kolom diperbesar dan jarak eksentrisitas terhadap d juga semakin semakin besar.

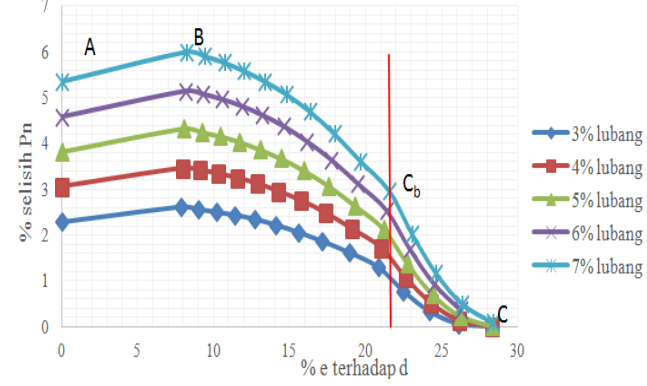

Gambar 5. Grafik Persentase Selisih $P_{n}$ terhadap Besaran Eksentrisitas

Persentase Selisih Mn Kolom Persegi Berlubang Terhadap Kolom Tidak Berlubang

Grafik persentase selisih $M_{n}$ terhadap besaran eksentrisitas memperlihatkan penurunan $\mathrm{Mn}_{\mathrm{n}}$ untuk masing-masing lubang. Dari grafik Gambar 6 dapat dilihat bahwa $\mathrm{M}_{\mathrm{n}}$ pada titik A bernilai nol, hal ini dikarenakan berada pada aksial murni sehingga tidak ada momen. Ketika $M_{n}$ pada kondisi tekan (titik B) mengalami kenaikan nilai dan pada titik tertentu pada kondisi tekan terdapat titik puncak (titik C) dan $\mathrm{M}_{\mathrm{n}}$ mengalami penurunan pada kondisi $\operatorname{tarik(titik} \mathrm{D}$ dan E). Hal ini disebabkan karena pada posisi penurunan wilayah momen bersentuhan langsung dengan lubang.

Persentase selisih $\mathrm{M}_{\mathrm{n}}$ terhadap besaran eksentrisitas dipengaruhi oleh beberapa faktor, yaitu: luas tulangan, jumlah tulangan, mutu beton, dimensi kolom.

1. Luas Tulangan

Persentase selisih $\mathrm{M}_{\mathrm{n}}$ tetap ketika luas tulangan diperbesar, akan tetapi jarak eksentrisitas terhadap d semakin besar ketika luas tulangan diperbesar.

2. Jumlah Tulangan

Persentase selisih $\mathrm{M}_{\mathrm{n}}$ tetap ketika jumlah tulangan tulangan diperbanyak, akan tetapi jarak eksentrisitas terhadap d semakin kecil ketika jumlah tulangan diperbanyak. 


\section{Mutu Beton}

Persentase selisih $\mathrm{M}_{\mathrm{n}}$ semakin besar ketika mutu beton semakin besar dan jarak eksentrisitas terhadap d semakin kecil ketika mutu beton diperbesar.

\section{Dimensi Kolom}

Persentase selisih $\mathrm{M}_{\mathrm{n}}$ semakin besar apabila dimensi kolom diperbesar dan jarak eksentrisitas terhadap d juga semakin semakin besar.

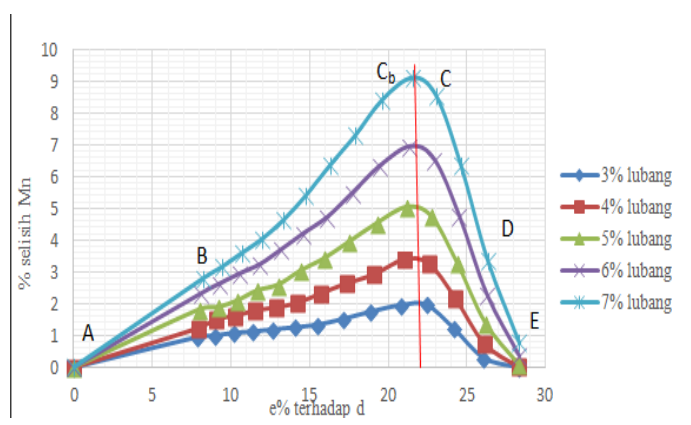

Gambar 6. Grafik Persentase Selisih $M_{n}$ terhadap Besaran Eksentrisitas

\section{Perbandingan Hasil Penelitian dengan} Penelitian Sebelumnya

Penelitian peneliti tentang "analisis kolom beton bertulang pada penampang persegi berlubang (tulangan longitudinal empat muka)" dibandingkan dengan penelitian Renjani, (2011) tentangan "analisis penampang kolom beton bertulang persegi berlubang (studi kasus tulangan longitudinal dua muka)". Perbedaan penelitian peneliti dengan penelitian Renjani, (2011) bisa dilihat pada Tabel 1 serta pada Gambar 7 dan Gambar 8.

Tabel 1. Perbandingan Hasil Penelitian

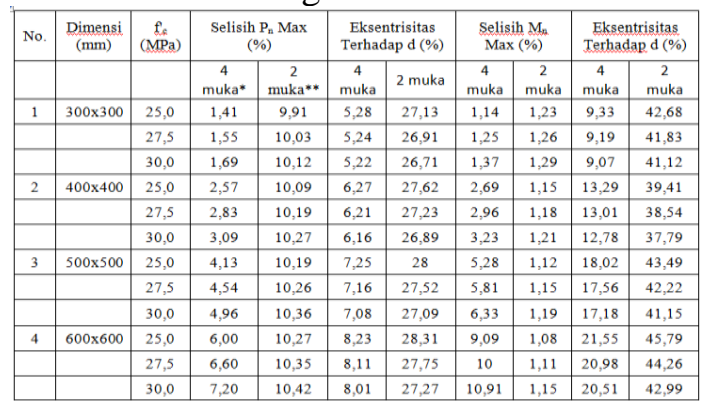

*Hasil Peneliti **Hasil Renjani, (2011)

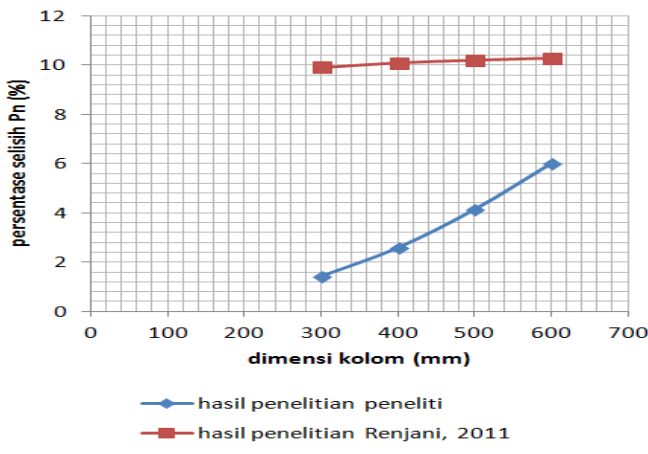

Gambar 8. Grafik Perbandingan Persentase Selisih $\mathrm{P}_{\mathrm{n}}$

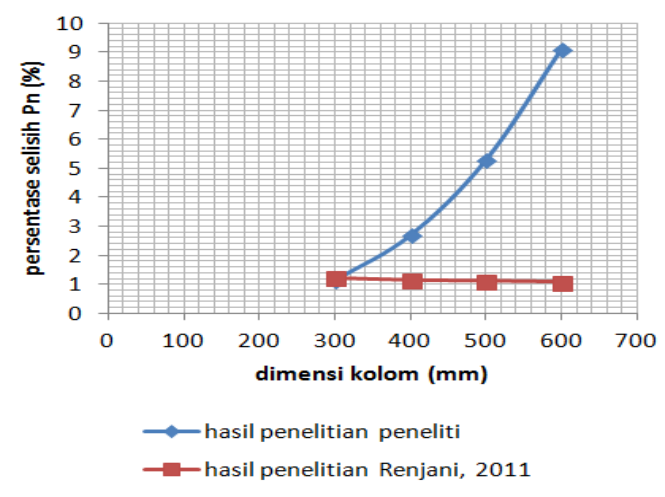

Gambar 9. Grafik Perbandingan Persentase Selisih $\mathrm{M}_{\mathrm{n}}$

\section{KESIMPULAN}

Kesimpulan yang dapat peneliti sampaikan dalam penelitian analisis kolom persegi berlubang pada kolom persegi berlubang yaitu:

1. $P_{n}$ dan $M_{n}$ antara kolom persegi berlubang dengan kolom persegi tidak berlubang terdapat perbedaan nilai. Nilai $P_{n}$ dan $M_{n}$ terjadi penurunan pada kolom persegi berlubang.

2. Persentase selisih $P_{n}$ maksimal sebesar $7,20 \%$ pada luasan lubang $7 \%$ dengan eksentrisitass terhadap d sebesar $8,01 \%$.

3. Persentase selisih $M_{n}$ maksimal sebesar $10,91 \%$ pada luasan lubang $7 \%$ dengan eksentrisitass terhadap d sebesar $20,51 \%$.

4. Persentase selisih $P_{n}$ dan $M_{n}$ tetap ketika luas tulangan dan jumlah tulangan diperbesar, akan tetapi jarak eksentrisitas terhadap d semakin besar apabila luas tulangan semakin besar dan jarak eksentrisitas terhadap d semakin kecil 
apabila jumlah tulangan semakin banyak.

6. Persentase selisih $P_{n}$ dan $M_{n}$ semakin besar apabila kekuatan mutu beton semakin besar dan jarak eksentrisitas terhadap d semakin kecil.

7. Persentase selisih $P_{n}$ dan $M_{n}$ semakin besar apabila dimensi kolom diperbesar dan jarak eksentrisitas terhadap $d$ juga semakin semakin besar.

\section{DAFTAR PUSTAKA}

Asroni, A., 2010. Kolom Fondasi dan Balok $T$ Beton Bertulang, Graha Ilmu,
Yogyakarta.

SNI 2847:2013. Persyaratan Beton Struktural untuk Bangunan Gedung. Badan Standarisasi Nasional Indonesia. Jakarta.

Renaningsih, 2006. Analisis Penempang Kolom Beton Bertulang Persegi Berlubang Menggunakan PCA-COL. Jurnal Ilmiah Teknik Sipil.

Renjani, M. S., 2011. Analisis Penampang Kolom Beton Bertulang Persegi Berlubang. Skripsi. Fakultas Teknik, Universitas Bengkulu. 